\title{
Tumor and host characteristics of small cell lung cancer (SCLC) in U.S. community oncology practice
}

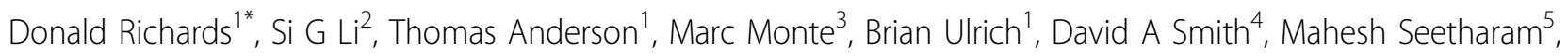
Paul Kaywin ${ }^{6}$, Ray Page ${ }^{7}$, Kimary Kulig $^{8}$, Cory Batenchuk ${ }^{8}$, Maen Hussein ${ }^{9}$

From 30th Annual Meeting and Associated Programs of the Society for Immunotherapy of Cancer (SITC 2015)

National Harbor, MD, USA. 4-8 November 2015

\section{Background}

The majority of lung cancer in the U.S. is treated in the community. A prospective cohort study of stage IV NSCLC and extensive disease (ED) SCLC is being conducted in 70 U.S. community practices to assess outcomes during the pre- and post-immunotherapy eras of lung cancer treatment. This analysis focuses on characteristics of the rarer SCLC subset in the pre-immunotherapy era.

\section{Methods}

ED SCLC patients, at any point in their care, with documented dates of diagnosis and prior treatment are eligible. Patients are followed prospectively for 36 months or until death, with data abstraction from medical records. Archival tumor tissue (formalin-fixed paraffin-embedded) slides are used to measure PD-L1 protein expression with a validated, automated immunohistochemistry (IHC) assay

Table 1 Summary of clinical attributes and PD-L1 Expression in SCLC

\begin{tabular}{|c|c|c|c|c|c|}
\hline Characteristic & Cohort & PD-L1 (<1\%) & PD-L1 ( $\geq 1 \%)$ & Frequency in PD-L1 $\geq 1 \%$ & Fisher (pV) \\
\hline \multirow[t]{2}{*}{ Smoking status } & EVER & 70 & 13 & $15.7 \%$ & \\
\hline & NEVER & 4 & 0 & $0.0 \%$ & 1.00 \\
\hline \multirow[t]{2}{*}{ Sex } & Male & 40 & 6 & $13.0 \%$ & \\
\hline & Female & 34 & 7 & $17.1 \%$ & 0.765 \\
\hline \multirow[t]{2}{*}{ ECOG } & $0-1$ & 49 & 7 & $12.5 \%$ & \\
\hline & $2-3$ & 21 & 6 & $22.2 \%$ & 0.335 \\
\hline \multirow[t]{2}{*}{ Age } & $<70$ & 47 & 5 & $10 \%$ & \\
\hline & $\geq 70$ & 27 & 8 & $23 \%$ & 0.126 \\
\hline \multirow[t]{2}{*}{ Autoimmune Disorders } & Present & 4 & 3 & $42.9 \%$ & \\
\hline & Absent & 68 & 9 & $11.7 \%$ & 0.057 \\
\hline \multirow[t]{3}{*}{ Site of biopsy for PDL1 samples* } & Primary & 37 & 6 & $14.0 \%$ & \\
\hline & Metastatic & 36 & 7 & $16.3 \%$ & \\
\hline & Primary/Metastatic & 1 & 0 & $0.0 \%$ & 1.000 \\
\hline \multirow[t]{2}{*}{ H\&E - Tumor Tissue Inflammation* } & Absent & 20 & 2 & $9.1 \%$ & \\
\hline & Present & 30 & 6 & $16.7 \%$ & 0.6971 \\
\hline \multirow[t]{2}{*}{ H\&E - Tumor Tissue Necrosis } & Absent & 31 & 3 & $8.8 \%$ & \\
\hline & Present & 19 & 5 & $20.8 \%$ & 0.2254 \\
\hline \multirow[t]{2}{*}{ H\&E-\% Intra-Tumoral Inflammatory Infiltrate* } & $<10 \%$ & 41 & 1 & $2.4 \%$ & \\
\hline & $\geq 10 \%$ & 30 & 10 & $33.3 \%$ & 0.003 \\
\hline
\end{tabular}

'US Oncology, Houston, TX, USA

Full list of author information is available at the end of the article

(0) 2015 Richards et al. This is an Open Access article distributed under the terms of the Creative Commons Attribution License (http:// creativecommons.org/licenses/by/4.0), which permits unrestricted use, distribution, and reproduction in any medium, provided the original work is properly cited. The Creative Commons Public Domain Dedication waiver (http://creativecommons.org/publicdomain/ zero/1.0// applies to the data made available in this article, unless otherwise stated. 
from Dako using the 28-8 antibody. Expression levels of tumor cell membrane staining at any intensity were defined for $\geq 1 \%$ and $\geq 5 \%$ of 100 assessable tumor cells.

\section{Results}

Data from 268 cases with complete records are reported. At enrollment, 95\% were ever smokers, 53\% female, and 26\% ECOG performance status (PS) 2 or 3 . The most prevalent sites of metastases were liver (34\%), bone (32\%), and brain (21\%). History of a specific autoimmune condition was present in $8 \%$ of cases. The median overall survival from diagnosis with extensive disease will be reported. PD-L1 IHC was performed on 96/268 patients with available tissue and was evaluable in $87 / 96$ cases. PD-L1 was expressed at $\geq 1 \%$ for 13 cases $(15 \%)$ and $\geq 5 \%$ for $2(2 \%)$ cases. Of these, 85 had hematoxylin and eosin (H\&E) staining performed showing tumor inflammation in $62 \%$ and tumor necrosis in $41 \%$ of cases. An intra-tumoral inflammatory infiltrate of $\geq 10 \%$ was observed in $49 \%$ of cases and is associated with PD-L1 expression at $\geq 1 \%$ $(P<0.003)$.

\section{Conclusion}

Many immunotherapy clinical trials exclude patients with active or untreated brain metastases and patients receiving treatment for autoimmune disease, yet a substantial proportion of community-based SCLC patients present with these attributes. PD-L1 expression levels in SCLC appear lower than those previously reported in NSCLC. The role of PD-L1 and other tumor and blood-based markers as prognostic or predictive for SCLC outcomes will be investigated in this ongoing study.

\section{Authors' details}

${ }^{1}$ US Oncology, Houston, TX, USA. ${ }^{2}$ BioStat Solutions, Inc., Frederick, MD, USA. ${ }^{3}$ Clopton Clinic of Jonesboro, Inc., Jonesboro, AR, USA. ${ }^{4}$ Compass Oncology, Vancouver, WA, USA. ${ }^{5}$ Arizona Oncology, Phoenix, AZ, USA. ${ }^{6}$ Miami Cancer Institute, Baptist Health Medical Group, Miami, FL, USA. ${ }^{7}$ The Center for Cancer and Blood Disorders, Fort Worth, TX, USA. ${ }^{8}$ Bristol-Myers Squibb, Princeton, NJ, USA. ${ }^{9}$ Florida Cancer Specialists, Tavares, FL, USA.

Published: 4 November 2015
doi:10.1186/2051-1426-3-S2-P170

Cite this article as: Richards et al: Tumor and host characteristics of small cell lung cancer (SCLC) in U.S. community oncology practice. Journal for ImmunoTherapy of Cancer 2015 3(Suppl 2):P170.

\section{Submit your next manuscript to BioMed Central} and take full advantage of:

- Convenient online submission

- Thorough peer review

- No space constraints or color figure charges

- Immediate publication on acceptance

- Inclusion in PubMed, CAS, Scopus and Google Scholar

- Research which is freely available for redistribution

Submit your manuscript at www.biomedcentral.com/submit 